\title{
RANCANG BANGUN SISTEM INFORMASI AKADEMIK FMIPA UNIVERSITAS TADULAKO BERBASIS ANDROID
}

\author{
W. F. Prasetyo ${ }^{1}$, I W. Sudarsana ${ }^{2}$ dan D. Lusiyanti ${ }^{3}$ \\ 1,2,3Program Studi Matematika Jurusan Matematika FMIPA Universitas Tadulako \\ Jalan Soekarno-Hatta Km. 09 Tondo, Palu 94118, Indonesia. \\ 1w14081994@live.com, 2sudarsanaiwayan@yahoo.co.id, 3desylusiyanti@gmail.com
}

\begin{abstract}
Academic information system based on Android necessary to support the effectiveness management of academic data such as input card study plan and input the value of course. To build Siakad Android application, the authors do the research of the database web Siakad Faculty of Natural Science Tadulako University that includes all the data of students, faculty, courses, card study plan, and card study result. The purpose of this study was to obtain academic information system based on Android Tadulako University Faculty of Mathematics and Natural Sciences. This application is built with features such as view bio, view the result of study, view the transcript, input study plan card, input result study card, wait confirm of study plan, and confirm study plan. Based on the results and discussion, it can be concluded that academic information system can support the effectiveness of academic data processing, such as the study plan input, and the input value of the course.
\end{abstract}

Keywords : : Academic Information System, Android, MySQL.

\section{ABSTRAK}

Sistem informasi akademik berbasis Android atau lebih dikenal dengan Siakad Android di perlukan dalam menunjang keefektifan dalam pengelolaan data akademik seperti pengurusan kartu rencana studi (KRS) dan input nilai mata kuliah. Untuk membangun aplikasi Siakad android ini, penulis melakukan penelitian terhadap database Siakad Web FMIPA Universitas Tadulako yang mencakup seluruh data mahasiswa, dosen, mata kuliah, krs, dan khs. Adapun tujuan penelitian ini adalah untuk mendapatkan sistem informasi akademik Fakultas FMIPA UNTAD berbasis Android. Aplikasi ini di bangun dengan fitur-fitur seperti melihat biodata, melihat hasil studi, melihat transkrip nilai, mengisi kartu rendaca studi, menunggu konfirmasi kartu rencana studi, perwalian, dan input nilai. Berdasarkan hasil dan pembahasan, dapat disimpulkan bahwa sistem informasi akademik berbasis Android dapat menunjang efektivitas pengolahan data akademik seperti pengurusan krs dan input nilai.

Kata kunci $\quad$ : Sistem Informasi Akademik, Android, MySQL. 


\section{PENDAHULUAN}

Sistem informasi akademik pada sebuah universitas merupakan suatu sistem yang sangat penting bagi mahasiswa dan juga dosen dalam melaksanakan kegiatan akademik. Sistem informasi akademik dapat digunakan untuk melihat jumlah presensi, melihat nilai dan indeks prestasi, melakukan pengisian kartu rencana studi dan input nilai. Karena sistem informasi akademik merupakan elemen penting pada sebuah universitas, sehingga sistem informasi tersebut harus senantiasa diberikan pemeliharaan (maintenance) dan pengembangan (development).

Pengembangan pada sistem informasi akademik dilakukan agar performa sistem semakin baik dan lebih efisien. Begitu juga dengan sistem informasi akademik yang ada di Fakultas FMIPA Universitas Tadulako. Pengembangan sistem informasi akademik dilakukan untuk menciptakan kemudahan bagi dosen dan mahasiswa untuk mendapatkan informasi dan melakukan aktifitas akademik khususnya dalam pengisian kartu rencana studi dan input nilai. Namun, sampai saat ini sistem informasi akademik Fakultas FMIPA Universitas Tadulako belum berkembang pada perangkat mobile berbasis Android (Hadi, 2010).

\section{METODE PENELITIAN}

Penelitian ini dilakukan sesuai prosedur sebagai berikut.

1. Pengambilan data.

Pengambilan data dilakukan di ruang ITC Fakultas MIPA Universitas Tadulako. Jenis data yang digunakan yaitu data kuantitatif dengan 3 (tiga) bentuk, yaitu Integer, Date, dan String. Sedangkan sumber data sekunder yang digunakan dalam penelitian ini adalah Database MySQL SIAKAD FMIPA UNTAD.

2. Analisa dan definisi persyaratan.

Analisa dan definisi persyaratan di lakukan untuk membatasi akses yang dilakukan oleh pengguna. Adapun analisa dan definisi persyaratan sebagai berikut.

a. Jumlah maksimal sks yang dapat di ambil oleh mahasiswa berdasarkan indeks prestasi pada semester sebelumnya.

b. Nilai mata kuliah hanya dapat di isi oleh dosen penanggung jawab mata kuliah tersebut.

c. Pengurusan krs hanya dapat di lakukan pada waktu yang telah di tentukan.

3. Perancangan sistem android.

Perancangan sistem android di lakukan untuk membentuk kerangka sistem seperti desain dan kode program. Perancangan sistem android di lakukan dengan melihat fitur-fitur dan definisi persyaratan Siakad FMIPA Universitas Tadulako seperti menampilkan biodata, krs, khs, pengisian krs, dan pengisian DPNA.

4. Simulasi / uji performasi sistem.

Simulasi ini di lakukan untuk melihat keberhasilan sistem Siakad Android. Jika pada simulasi masih terdapat kesalahan, maka di lakukan kembali perancangan sistem android ini. 


\section{HASIL DAN PEMBAHASAN}

\subsection{Rancangan Proses}

Rancangan proses menunjukkan output dan input sebuah sistem dimana terdapat elemen atau entitas yang berhubungan dengan sistem tersebut (Sikha dkk, 2004).

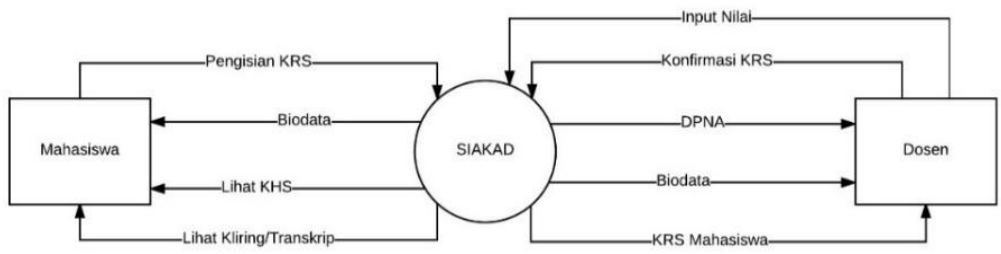

Gambar 1 : Rancangan Proses Sistem Informasi Akademik FMIPA UNTAD.

Dalam diagram konteks rancangan proses sistem informasi akademik Fakultas Matematika dan IImu Pengetahuan Alam Universitas Tadulako berbasis Android ini memiliki 2 (dua) kesatuan atau entitas (entity) yaitu mahasiswa dan dosen. Rancangan proses sistem Siakad ini memiliki 6 proses output dan 3 proses input yaitu 3 output oleh mahasiswa, 3 output oleh dosen, 1 input oleh mahasiswa, dan 2 input oleh dosen. Pada gambar 1, terlihat adanya sistem Siakad dengan 2 entitas yaitu mahasiswa dan dosen yang terdapat hubungan input dan output diantaranya output biodata oleh siakad untuk mahasiswa dan dosen, output khs oleh siakad untuk mahasiswa, output transkrip nilai oleh siakad untuk mahasiswa, output DPNA oleh siakad untuk dosen, output krs mahasiswa oleh siakad untuk dosen, pengisian krs oleh mahasiswa untuk siakad, konfirmasi krs oleh dosen untuk siakad, dan input nilai oleh dosen untuk siakad (Rahmat, 2010).

\subsection{Rancangan Diagram Relasi}

Diagram relasi menunjukkan hubungan antara tabel satu dengan tabel yang lainnya. Setiap tabel yang ada harus terhubung dengan satu atau beberapa tabel lainnya secara logis. Tiap-tiap tabel memiliki kolom Primary key sebagai kunci penghubung antar tabel. Primary key merupakan atribut kunci dalam tabel yang unik atau tunggal. Sedangkan Foreign key adalah atribut kunci sebuah tabel yang ada di tabel lain. 


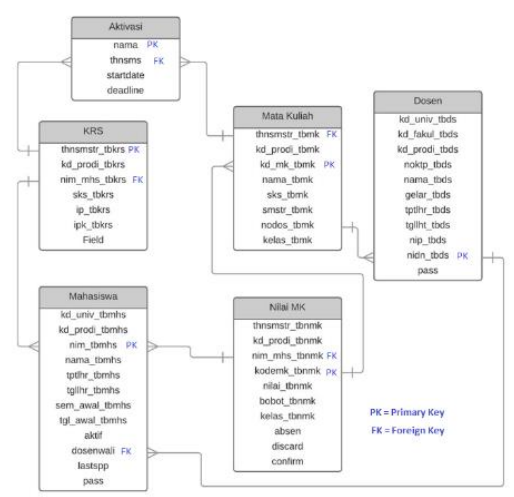

Gambar 2 : Rancangan Diagram Relasi.

Diagram relasi atau hubungan pada database Siakad Android (Gambar 2) menunjukkan adanya hubungan antara tabel aktivasi, matakuliah, krs, dosen, mahasiswa, dan nilai mata kuliah.

\subsection{Rancangan Diagram Hubungan Entitas (ERD)}

Diagram EDR Sistem Fakultas Matematika dan IImu Pengetahuan Alam Universitas Tadulako pada gambar 3, memiliki 5 entitas yaitu Dosen, Mahasiswa, Mata Kuliah, Nilai Mata Kuliah, dan Kartu Rencana Studi. Serta memiliki 6 relationships atau hubungan yakni dosen mengajar matakuliah, matakuliah diambil mahasiswa, nilai mk di lihat mahasiswa, dosen menginput nilai mk, mahasiswa mengambil krs, dan dosen mengkonfirmasi krs.

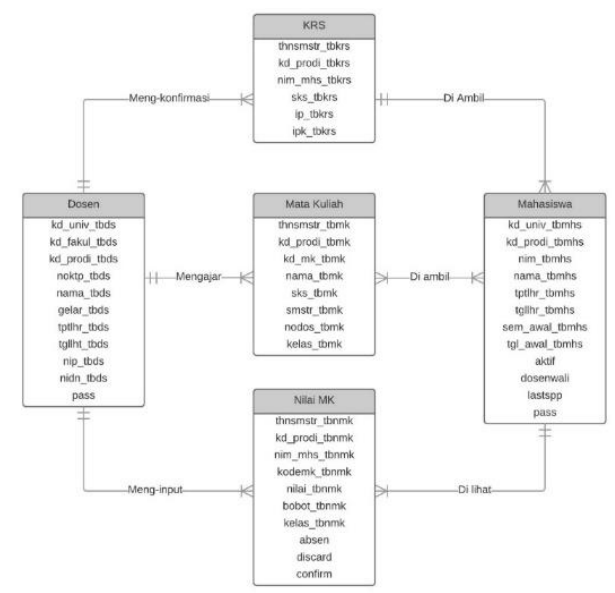

Gambar 3 : Rancangan Diagram Hubungan Entitas (ERD).

Hubungan antara dosen dengan krs yaitu meng-konfirmasi, dimana satu dosen dapat meng-konfirmasi satu krs dan satu dosen dapat dapat meng-konfirmasi banyak krs. Hubungan antara dosen dengan mata kuliah yaitu mengajar, dimana satu dosen dapat mengajar satu mata kuliah dan satu dosen dapat mengajar banyak mata kuliah. Hubungan antara dosen dengan nilai mata kuliah yaitu meng-input, dimana satu dosen dapat meng-input satu mata 
kuliah dan satu dosen dapat meng-input banyak mata kuliah. Hubungan antara krs dengan mahasiswa yaitu diambil, dimana satu krs dapat diambil oleh satu mahasiswa dan satu krs dapat diambil oleh banyak mahasiswa. Hubungan antara mata kuliah dengan mahasiswa yaitu diambil, dimana satu mata kuliah dapat diambil oleh satu mahasiswa, satu mata kuliah dapat diambil oleh banyak mahasiswa, banyak mata kuliah dapat diambil oleh satu mahasiswa, dan banyak mata kuliah dapat diambil oleh banyak mahasiswa. Hubungan antara nilai mata kuliah dengan mahasiswa yaitu dilihat, dimana satu nilai mata kuliah dapat dilihat oleh satu mahasiswa dan banyak mata kuliah dapat dilihat oleh satu mahasiswa (Kusrini, 2007).

\subsection{Hasil dan Pembahasan}

Berdasarkan perancangan yang dibuat maka dihasilkan sebuah Sistem Informasi Akademik Fakultas Matematika dan IImu Pengetahuan Alam Universitas Tadulako berbasis Android. Adapun rancangan tabel di dibuat seperti berikut.

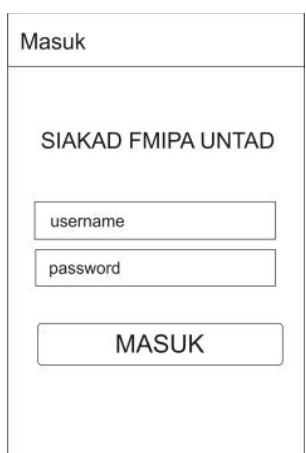

(a)

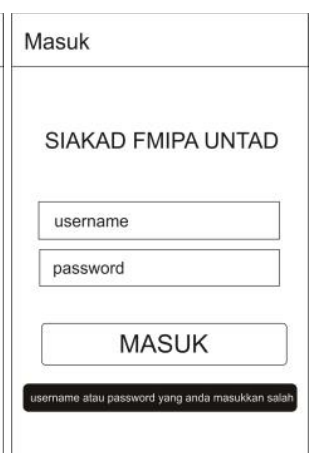

(b)

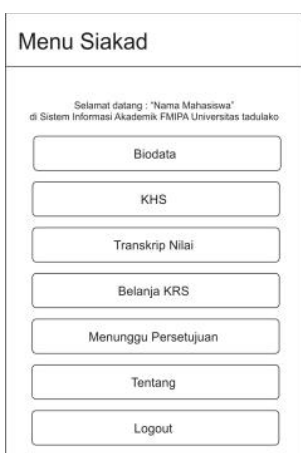

(c)

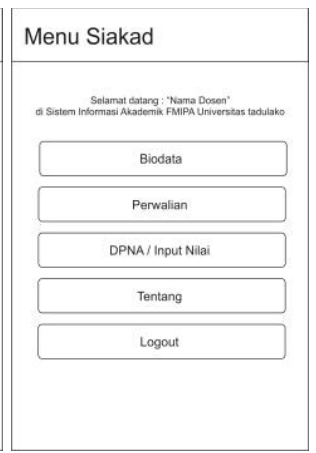

(d)

\begin{tabular}{|l||l|}
\hline Menu Siakad & Menu Siakad \\
\hline Nama: & Nama : \\
Stambuk: & NIDN: \\
Tanggal Lahir: & Alamat: \\
\hline & \\
\hline
\end{tabular}

(e) (f)

\begin{tabular}{|lll|}
\hline \multicolumn{2}{|l|}{ Menu Siakad } \\
\hline Semester & IP & SKS \\
\hline 20161 & 3.00 & 24 \\
\hline & & \\
\hline & & \\
\hline & \\
\hline \\
\hline \\
\hline
\end{tabular}

(g)

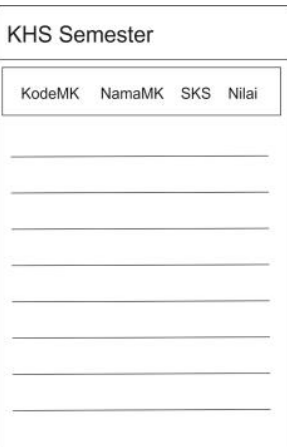

(h) 


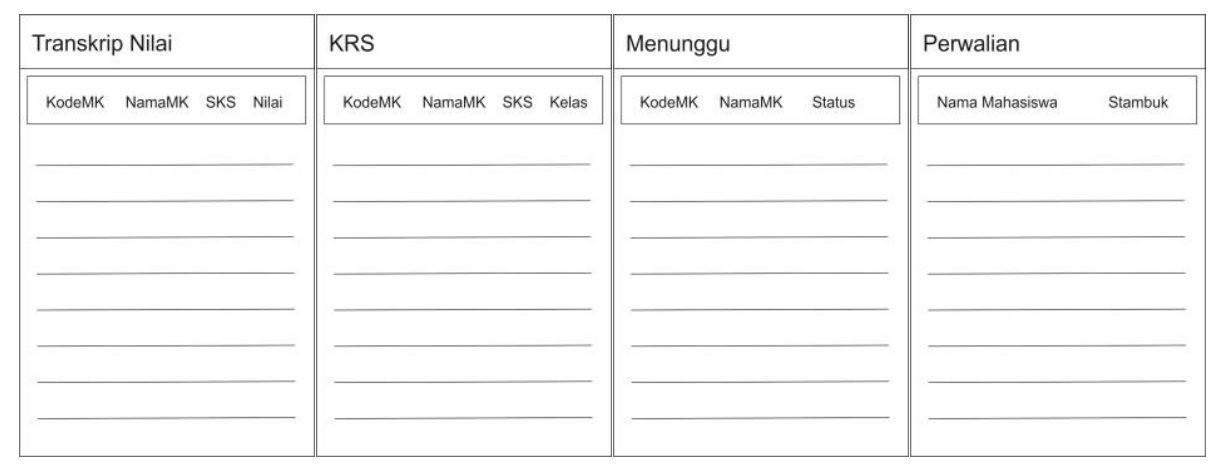

(i)

(j)

(k)

(I)

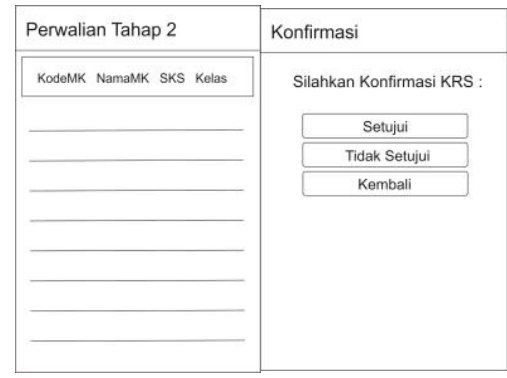

(m) (n)

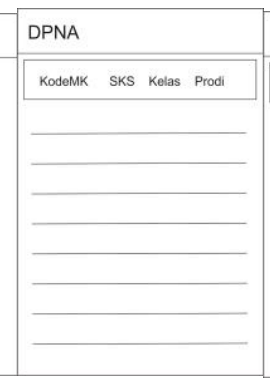

(o)

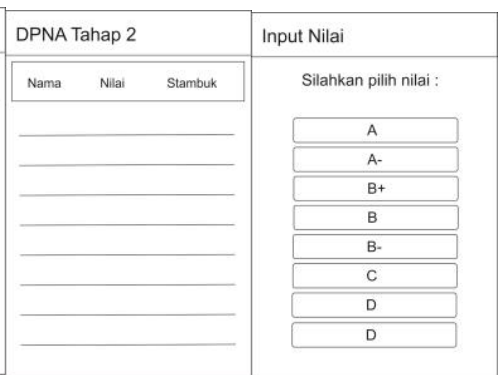

(p) (q)

Gambar 4 : Konstruksi Tampilan Aplikasi Siakad Android, yaitu : (a) Login, (b) Login saat username atau password salah, (c) Menu Siakad untuk Mahasiswa, (d) Menu Siakad untuk Dosen, (e) Biodata mahasiswa, (f) Biodata dosen, (g) KHS per semester, (h) KHS pada semester yang di pilih, (i) Transkrip nilai, (j) Belanja KRS, (k) Menunggu persetujuan, (I) Menu Perwalian, (m) Perwalian tahap 2, (n) Konfirmasi perwalian, (o) DPNA, (p) DPNA tahap 2, dan (q) Input nilai.

\subsubsection{Rancangan Sistem Login}

Sistem login pada aplikasi ini menggunakan sistem SharedPreferences, yaitu pada saat mahasiswa atau dosen melakukan login dengan username atau password yang benar, maka data berupa username, password, nama dan sebagainya akan tersimpan di pada variabel SharedPreferences yang telah di tentukan. SharedPreferences yang tersimpan akan dipanggil saat memilih menu-menu yang lain (Onur, 2015).

\subsubsection{Rancangan Sistem Menu Mahasiswa}

Sistem pada menu mahasiswa memanfaatkan data variabel yang tersimpan di SharedPreferences. Variabel tersebut akan digunakan untuk memanggil data dari database MySQL. Pada menu mahasiswa ini, terdapat 7 menu yang terdiri dari biodata, lihat khs, lihat transkrip, belanja krs, menunggu persetujuan, tentang, dan logout. 


\subsubsection{Rancangan Sistem Biodata Mahasiswa}

Sistem pada biodata mahasiswa memanfaatkan data variabel username yang tersimpan di SharedPreferences. Variabel username tersebut akan digunakan untuk memanggil data biodata dari database MySQL. Desain pada tampilan biodata ini hanya menggunakan TextView untuk menampilkan biodata. Biodata yang di tampilan yaitu : nama, stambuk, tempat lahir, tanggal lahir, jenis kelamin, tahun masuk, dosen wali, alamat, nomor handphone, alamat wali, dan nomor handphone wali.

\subsubsection{Rancangan Sistem Kartu Hasil Studi}

Sistem pada KHS memanfaatkan data variabel username yang tersimpan di SharedPreferences. Variabel username tersebut akan digunakan untuk memanggil data KHS dari database MySQL. Sistem KHS ini memanggil data berupa KHS per semester. Saat semester dipilih maka akan langsung muncul tampilan mata kuliah pada semester yang di pilih tersebut.

\subsubsection{Rancangan Sistem Transkrip Nilai}

Sistem pada Transkrip Nilai memanfaatkan data variabel username yang tersimpan di SharedPreferences. Variabel username tersebut akan digunakan untuk memanggil data seluruh mata kuliah yang di lulusi dari database MySQL.

\subsubsection{Rancangan Sistem Belanja KRS atau Input KRS}

Sistem pada Belanja KRS memanfaatkan data variabel username, prodi, dan tahun ajaran yang tersimpan di SharedPreferences. Variabel username, prodi, dan tahun ajaran tersebut akan digunakan untuk memanggil data seluruh mata kuliah pada prodi dan tahun ajaran yang berlangsung dari database MySQL. Saat mata kuliah dipilih, maka akan menampilkan pertanyaan "apakah anda yakin mengambil mata kuliah ini ?".

\subsubsection{Rancangan Sistem Menunggu Persetujuan KRS}

Sistem pada Menunggu Persetujuan memanfaatkan data variabel username dan tahun ajaran yang tersimpan di SharedPreferences. Variabel username dan tahun ajaran tersebut akan digunakan untuk memanggil data seluruh mata kuliah pada tahun ajaran yang berlangsung dari database MySQL. Saat mata kuliah disetujui dosen, maka akan muncul tulisan "disetujui" bewarna hijau. Saat mata kuliah belum disetujui dosen, maka akan muncul tulisan "menunggu". Saat mata kuliah tidak disetujui dosen, maka akan muncul tulisan "ditolak" berwarna merah.

\subsubsection{Rancangan Sistem Menu Dosen}


Sistem pada menu dosen memanfaatkan data variabel yang tersimpan di SharedPreferences. Variabel tersebut akan digunakan untuk memanggil data dari database MySQL. Pada menu dosen ini, terdapat 5 menu yang terdiri dari biodata, perwalian, DPNA / Input Nilai, tentang, dan logout.

\subsubsection{Rancangan Sistem Biodata Dosen}

Sistem pada biodata dosen memanfaatkan data variabel username yang tersimpan di SharedPreferences. Variabel username tersebut akan digunakan untuk memanggil data biodata dari database MySQL. Desain pada tampilan biodata ini hanya menggunakan TextView untuk menampilkan biodata. Biodata yang di tampilan yaitu : nama, gelar, NIDN, NIP lama, NIP baru, Nomor KTP, tempat lahir, tanggal lahir, dan jenis kelamin.

\subsubsection{Rancangan Sistem Perwalian atau Konfirmasi KRS}

Sistem pada perwalian memanfaatkan data variabel username dan tahun ajaran yang tersimpan di SharedPreferences. Variabel username dan tahun ajaran tersebut akan digunakan untuk memanggil data mahasiswa dengan status aktif dari database MySQL. Desain tampilan pada sistem perwalian ini berupa list mahasiswa beserta stambuknya. Saat ada mata kuliah yang belum terkonfirmasi, maka nama dari mahasiswa yang belum terkonfirmasi tersebut akan berwarna merah. Saat semua mata kuliah dari mahasiswa sudah terkonfirmasi semua, maka nama dari mahasiswa tersebut akan berwarna biru. Saat ada mahasiswa yang belum mengambil mata kuliah, maka nama dari mahasiswa tersebut akan berwarna abu-abu. Ketika dosen memilih nama mahasiswa, maka akan diarahkan ke tampilan daftar mata kuliah yang terambil. Jika nama mata kuliah berwarna hijau, artinya mata kuliah tersebut telah disetujui. Jika berwarna merah, maka mata kuliah tersebut tidak disetujui. Dan jika berwarna biru, berarti mata kuliah tersebut belum di konfirmasi.

\subsubsection{Rancangan Sistem DPNA atau Input Nilai}

Sistem pada DPNA/Input Nilai memanfaatkan data variabel username, startdate DPNA, dan deadline DPNA yang tersimpan di SharedPreferences. Startdate artinya waktu mulai pengurusan, sedangkan deadline adalah batas akhir pengurusan. Variabel startdate DPNA, dan dead line DPNA tersebut akan digunakan untuk memanggil data mata kuliah yang di ajarkan pada tahun ajaran berlangsung dari database MySQL. Desain tampilan pada sistem perwalian ini berupa list mata kuliah beserta kelas dan prodinya. Ketika dosen memilih nama mata kuliah tersebut, maka akan diarahkan ke tampilan daftar nama mahasiswa yang mengambil mata kuliah tersebut beserta nilainya. Saat nama mahasiswa tersebut di pilih, maka langsung muncul tampilan input 
nilai berupa 8 tombol nilai A, A-, B+, B, B-, C, D, dan E. Saat dosen memilih nilai, maka akan kembali ke daftar mahasiswa tersebut.

\subsection{Flowchart dan Pseudo-code}

\subsubsection{Flowchart}

Flowchart adalah adalah suatu bagan dengan simbol-simbol tertentu yang menggambarkan urutan proses secara mendetail dan hubungan antara suatu proses (instruksi) dengan proses lainnya dalam suatu program. Flowchart proses Siakad FMIPA UNTAD berbasis Android terlihat pada Gambar 5 .

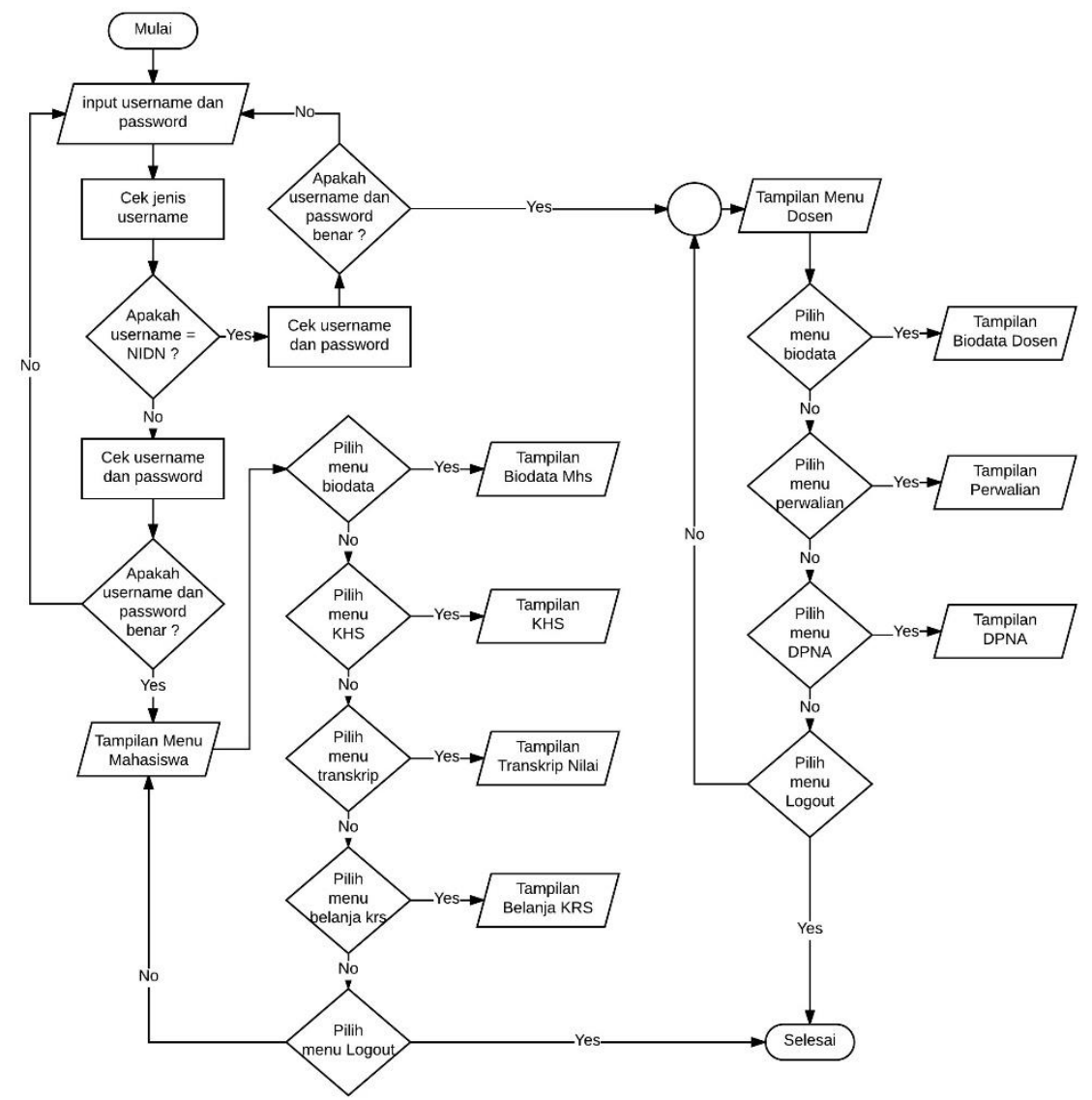

Gambar 5 : Flowchart aplikasi Siakad FMIPA UNTAD Berbasis Android.

\subsubsection{Pseudo-code}

Kode Pseudo (Pseudo-code) adalah sebuah kode yang digunakan untuk menulis sebuah algoritma dengan cara yang bebas yang tidak terikat dengan bahasa pemrograman tertentu. Pseudo-code berisikan langkah-langkah untuk menyelesaikan suatu permasalahan (hampir sama dengan algoritma), hanya saja bentuknya sedikit berbeda dari algoritma. 
Pseudo-code menggunakan bahasa yang hampir menyerupai bahasa pemrograman. Selain itu biasanya pseudo-code menggunakan bahasa yang mudah dipahami secara universal dan juga lebih ringkas dari pada algoritma. Berikut ini adalah Pesudo-code dari rancangan aplikasi Siakad FMIPA Universitas Tadulako berbasis Android.

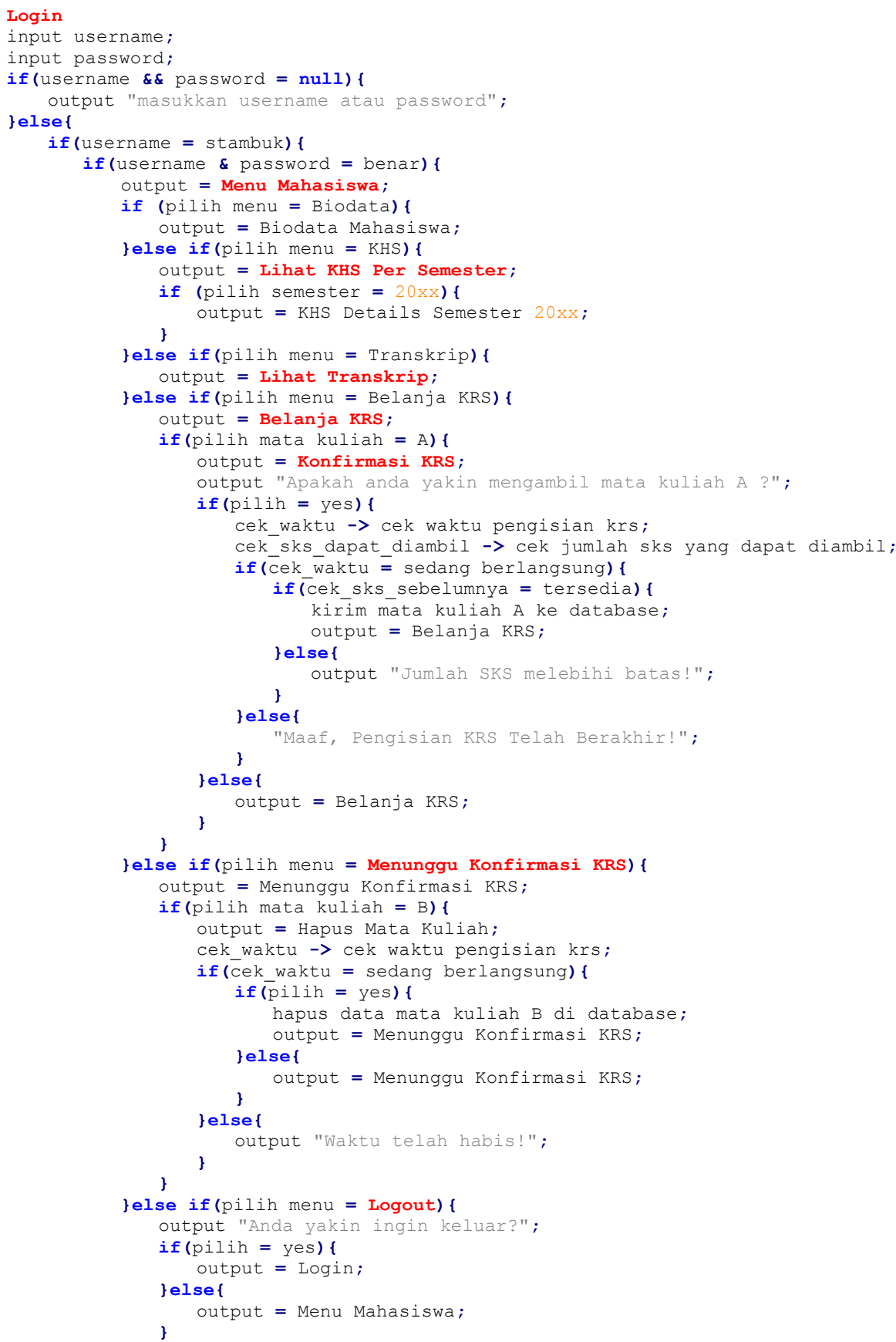




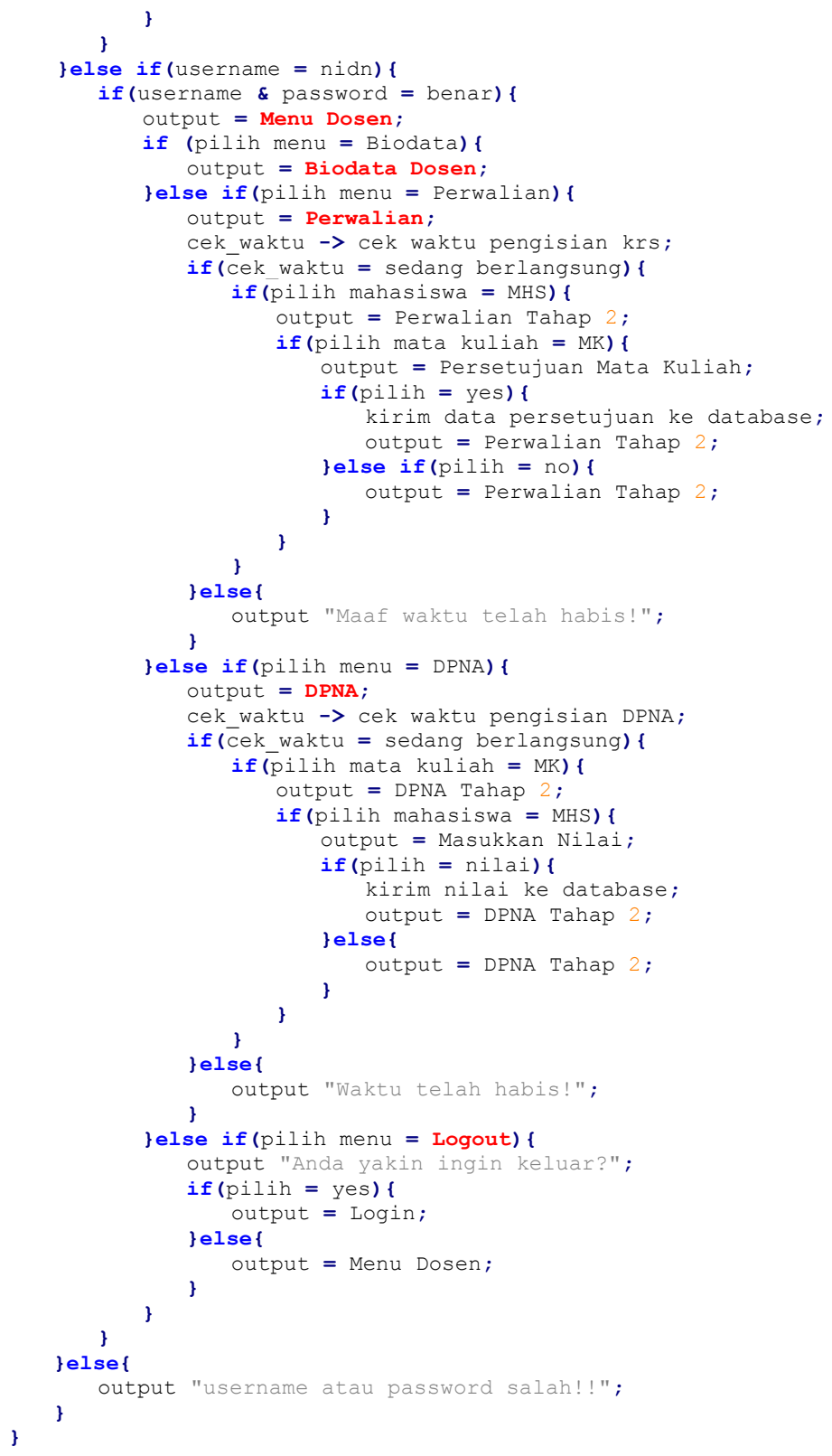




\subsection{Simulasi / Uji Performansi Sistem}

Adapun hasil simulasi yang di lakukan diperlihatkan pada Gambar 5 berikut.

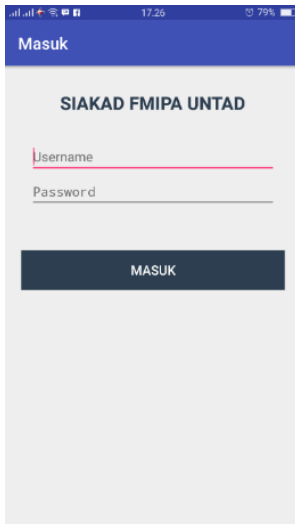

(a)

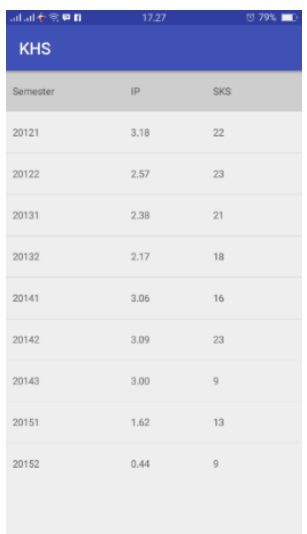

(d)

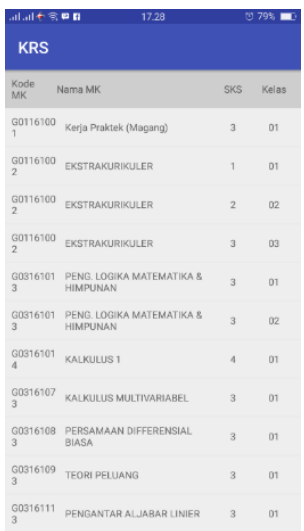

(g)
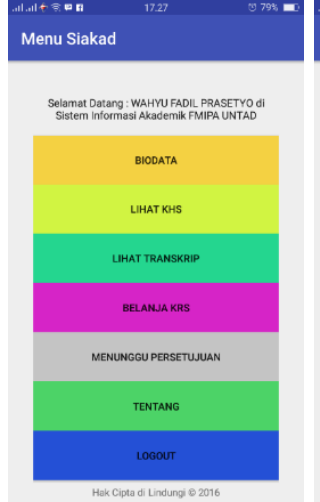

(b)

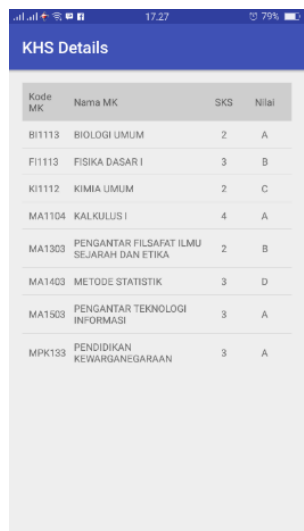

(e)
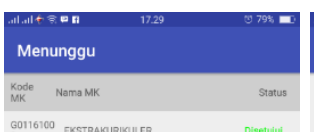

G0316122 SKPIPSI

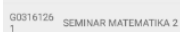

G0316766 MATEMATIKA CTRRA

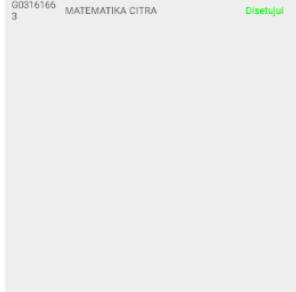

(h)

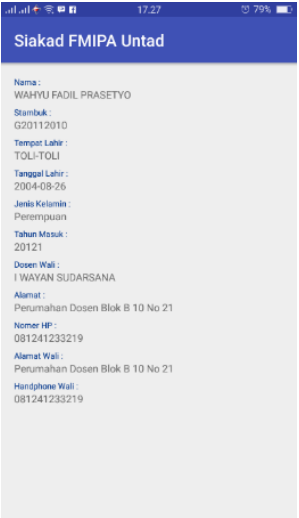

(c)

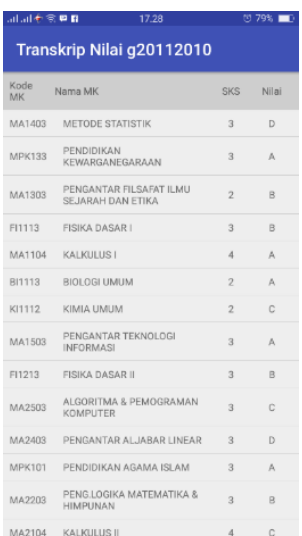

(f)
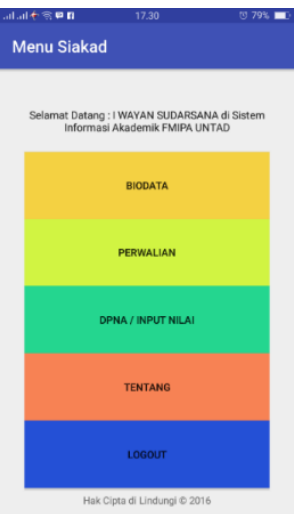

(i) 


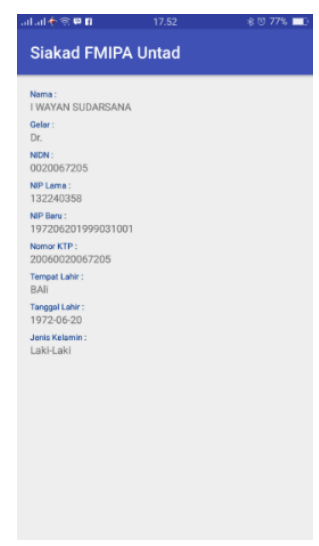

(j)

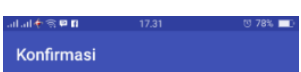

Pilih Salah Satu :

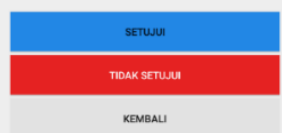

(m)

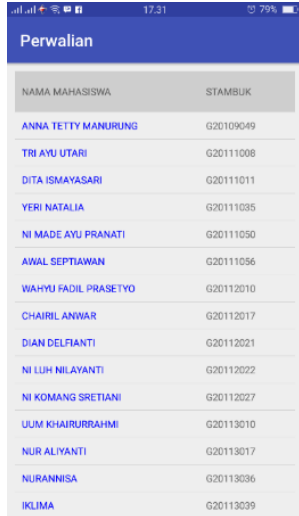

(k)

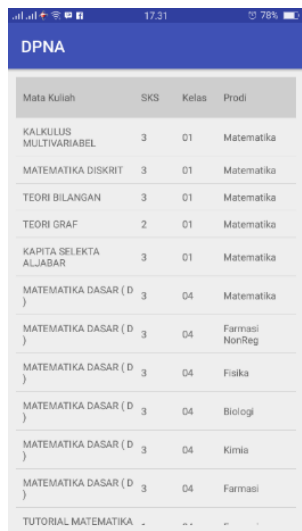

(n)

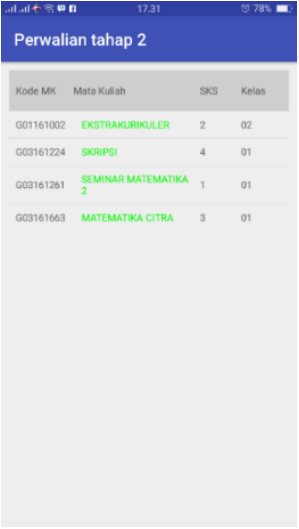

(l)

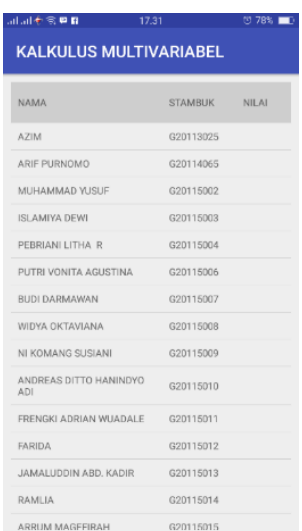

(o)

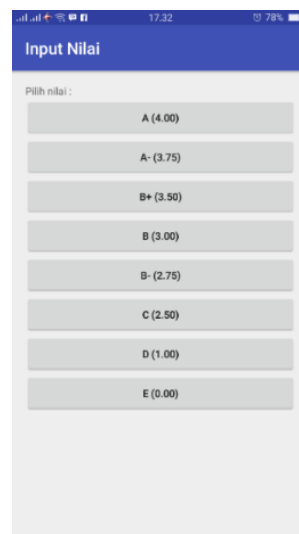

(p)

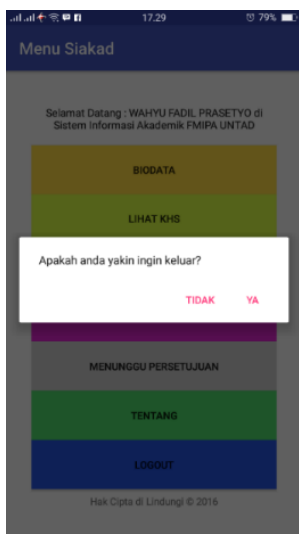

(q)

Gambar 6 : Tampilan Simulasi Siakad Android FMIPA UNTAD diantaranya: (a) Tampilan login, (b) tampilan menu mahasiswa, (c) tampilan biodata mahasiswa, (d) tampilan khs per semester, (e) tampilan khs yang dipilih, (f) tampilan transkrip nilai, (g) tampilan input krs, (h) tampilan menunggu konfirmasi krs oleh dosen, (i) tampilan menu dosen, (j) tampilan biodata 
dosen, (k) tampilan perwalian, (l) tampilan perwalian tahap kedua, (m) tampilan konfirmasi krs, (n) tampilan dpna atau penginputan nilai, (o) tampilan mahasiswa yang akan di input nilainya berdasarkan mata kuliah, (p) tampilan input nilai, dan (q) tampilan logout.

\subsubsection{Uji Coba Memulai Aplikasi}

Uji coba menjalankan aplikasi SIAKAD Fakultas Matematika dan IImu Pengetahuan Alam Universitas Tadulako di katakan berhasil jika aplikasi berjalan dengan baik tanpa ada error apapun ketika di jalankan.

\subsubsection{Uji Coba Login Siakad}

Pada tampilan login, mahasiswa atau dosen harus memasukkan username dan password yang benar pada form login untuk masuk ke menu SIAKAD. Jika username dan password salah, maka akan muncul pesan "username atau password salah !!!". Jika benar, tampilan menu SIAKAD aplikasi akan muncul. Jika form username atau password tidak di isi, maka akan muncul peringatan "required" atau "harus di isi" dan mahasiswa atau dosen tidak dapat menekan tombol Masuk.

\subsubsection{Uji Coba Fitur Belanja KRS dan Perwalian KRS}

Fitur belanja KRS muncul saat mahasiswa memilih menu belanja krs pada menu SIAKAD. Fitur perwalian KRS muncul saat dosen memilih menu perwalian KRS pada menu SIAKAD. Fitur belanja KRS digunakan mahasiswa untuk mengajukan mata kuliah yang akan di ambil pada semester yang berlangsung. Fitur perwalian KRS digunakan dosen untuk mengkonfirmasi KRS yang telah diambil oleh mahasiswa perwaliannya. Jika mahasiswa telah mengambil atau menambah mata kuliah untuk semester berikutnya, maka otomatis mata kuliah yang dipilih akan terkirim ke dosen wali mahasiswa tersebut untuk di konfirmasi dan disetujui. Jika belum ada konfirmasi atau respon dari dosen wali, maka akan muncul daftar mata kuliah dengan status "menunggu" pada menu hapus KRS. Jika KRS yang di ambil telah disetujui, maka akan muncul daftar mata kuliah dengan status "si setujui" pada menu hapus KRS. Pada menu konfirmasi KRS, dosen dapat menghapus atau tidak menyetujui mata kuliah yang diambil oleh mahasiswa. Uji coba fitur tambah KRS dan konfirmasi KRS berhasil jika semua proses tambah krs dan konfirmasi KRS dapat berjalan dengan baik.

\subsubsection{Uji Coba Hapus KRS}

Fitur hapus KRS muncul saat mahasiswa memilih menu Hapus KRS pada menu SIAKAD. Fitur hapus KRS digunakan mahasiswa untuk menghapus atau membatalkan mata kuliah yang telah di ambil pada semester yang sedang berlangsung. Uji coba fitur hapus KRS berhasil jika setelah mahasiswa berhasil menghapus atau membatalkan mata kuliah yang telah diambil. 


\subsubsection{Uji Coba Fitur Lihat KHS untuk Mahasiswa}

Fitur lihat KHS muncul saat mahasiswa memilih menu Lihat KHS pada menu SIAKAD. Fitur Lihat KHS digunakan mahasiswa untuk menampilkan semua KHS di tiaptiap semester. Informasi yang di dapat pada menu Lihat KHS adalah nilai mata kuliah dan indeks prestasi per semester. Uji coba fitur Lihat KHS dikatakan berhasil jika KHS dapat tampil dengan baik.

\subsubsection{Uji Coba Fitur Input Nilai DPNA}

Fitur input nilai muncul saat dosen memilih menu input nilai pada menu SIAKAD. Fitur input nilai digunakan dosen untuk menginput nilai mahasiswa sesuai mata kuliah yang di sedang di ajarkan pada semester yang berlangsung. Uji coba fitur input nilai dikatakan berhasil jika nilai dapat terinput dengan baik tanpa ada error apapun.

\subsubsection{Uji Coba Fitur Logout}

Fitur Logout digunakan untuk keluar dari sesi yang sedang aktif. Saat pengguna memilih fitur Logout, maka mahasiswa atau dosen akan dibawa ke menu Login SIAKAD.

\section{KESIMPULAN}

Dengan mengikuti beberapa tahap dan proses penelitian perancangan Sistem Informasi Akademik Fakultas Matematika dan IImu Pengetahuan Alam Universitas Tadulako Berbasis Android dan telah berhasil mendapatkan aplikasi SIAKAD yang dapat di gunakan di perangkat Android dan memiliki beberapa fitur berupa :

1. Pengisian kartu rancangan studi oleh mahasiswa melalui aplikasi. Rancangan pengisian kartu rencana studi di tampilkan seperti dalam bentuk tabel dalam Gambar 4(j).

2. Konfirmasi kartu rancangan studi mahasiswa oleh dosen melalui aplikasi. Rancangan konfirmasi kartu rencana studi di tampilkan seperti dalam bentuk tabel dalam Gambar 4(k) dan 4(I).

3. Menampilkan biodata oleh mahasiswa dan dosen melalui aplikasi. Rancangan biodata di tampilkan seperti dalam bentuk tabel dalam Gambar 4(e) dan 4(f).

4. Menampilkan kartu hasil studi tiap semester oleh mahasiswa melalui aplikasi. Rancangan kartu hasil studi di tampilkan dalam bentuk tabel dalam Gambar 4(h).

5. Menampilkan kliring atau transkrip nilai oleh mahasiswa melalui aplikasi. Rancangan kliring atau transkrip nilai di tampilkan seperti dalam bentuk tabel dalam Gambar 4(i).

6. Menginput nilai mata kuliah oleh dosen melalui aplikasi. Rancangan input nilai mata kuliah di tampilkan seperti dalam bentuk Tabel dalam Gambar 4(q). 


\section{DAFTAR PUSTAKA}

[1] Sikha, Bagui, \& Richard, Earp, Database Design Using Entity-Relationship Diagrams, New York, 2004, CRC Press.

[2] Onur, Cinar, Android Quick APls Reference, 2015, Apress.

[3] Rahmat, Hidayat, Cara Praktis Membangun Website Gratis, Jakarta, 2010, PT. Elex Media Komputindo.

[4] Hadi, Kurniawan, Pengertian Sistem Informasi Akademik, https://tipstategi.wordpress .com/2010/05/05/pengertian-sistem-informasi-akademik/, 2010, (diakses pada 15 januari 2016).

[5] Kusrini, Strategi Perancangan dan Pengelolaan Basis Data, Yogyakarta, 2007, PT. Andi. 